\title{
An Empirical Analysis on the Persistent Effects of Poverty Alleviation Program in China
}

\author{
Jiajie Zhang \\ School of Economics, Jinan University, Guangzhou, China \\ Email: 3089984566@qq.com
}

How to cite this paper: Zhang, J.J. (2016) An Empirical Analysis on the Persistent Effects of Poverty Alleviation Program in China. Modern Economy, 7, 1223-1231. http://dx.doi.org/10.4236/me.2016.711118

Received: September 5, 2016

Accepted: September 27, 2016

Published: September 30, 2016

Copyright (@) 2016 by author and Scientific Research Publishing Inc. This work is licensed under the Creative Commons Attribution International License (CC BY 4.0).

http://creativecommons.org/licenses/by/4.0/

\begin{abstract}
Using the 2011-2012 county-level panel data, the paper empirically investigates whether counties exited from the poverty alleviation program affect their economic growth. The identification uses the adjustment of lists of national poverty counties initiated by Chinese government in 2011. It shows that the poverty alleviation program leads to large gains in economy growth that are eventually reversed when the counties quit from the program. Besides, the fiscal revenues and expenditures significantly decline when previous national poverty counties are excluded from the lists.
\end{abstract}

\section{Keywords}

Previous National Poverty Counties, Poverty Alleviation Program, Economy Growth

\section{Introduction}

Over the past twenty years, China has made great achievements in the process of antipoverty. The poor population reduced from 70 million in 1994 to 26 million in 2010 and the incidence of poverty decreased from $7.6 \%$ to $2.8 \%$ [1] [2]. A large number of studies show that poverty alleviation program plays a great role in poverty alleviation. The last three poverty alleviation policies not only effectively have improved the income of local residents in the poor counties, but also have narrowed the gaps between poverty areas and developed areas [3]. However, it is difficult for poverty counties to give up the designation of national poverty counties and preferential treatment. Some economists warn that such regional targeted programs may become invalid in the long run, especially when the programs end [4] [5].

The paper evaluates the persistent effects of a large-scale poverty alleviation program instituted by the Chinese government in 2001. It is also called the third wave of China's poverty alleviation program. It covers 592 counties and contains over $60 \%$ poverty- 
stricken population in China [6]. The targets of the program are also known as national poverty counties. The targeted counties comfort with transfer payments and preferential development policies.

Over the course of its eleven-year operation from 2001 to 2011, the income and consumption of families in the poverty counties increase $6.1 \%$ and $9.2 \%$ respectively [7]. Also, it improves per capita net income of targeted peasants [8]. In 2011, Chinese government decides to trim the beneficiaries of the program and start a new (the fourth wave) poverty alleviation program. As a result, 38 counties exited from the poverty alleviation program because their per capita income was beyond the standard of the program.

In the paper, the difference-in-difference approach is applied to evaluate the impacts of withdrawing from the program for the previous national poverty counties. As such, the causal impacts of quitting the program can be gauged by comparing the counties remained in lists of the program after 2011. Besides, the paper also focuses on the impacts to the counties removed from the lists of the poverty alleviation program on fiscal revenues, expenditures, education and health.

The marginal contribution of this paper lies in: The paper figures out that the counties exited from poverty alleviation program in 2011 suffer the slowdown of economic growth. On average, the economic growth of previous national poverty counties deceases 7 percent when they quit. It is a supplement to researches of poverty alleviation program. Also, the study provides scientific guides for the development of povertystricken area. Besides, the paper points out that the fiscal revenues and expenditures of previous national poverty counties fall and their enrollments of secondary school decrease. It is beneficial for central government to draw up policies to improve the fiscal position and education of counties which have exited from the poverty program.

\section{Literature Review}

Lots of literatures have pointed out that the poverty alleviation program promotes both income of peasants in countries and economic growth. However, some scholars criticize that the effects of poverty alleviation program lag behind and lapse in the long term [4] [8] [9]. Many literatures have evaluated the policy effect of the second wave of program, which is also called "8-7 Plan", instead of the third wave of the program. Park et al. (2002) find that the "8-7 Plan" has increased the per capita net income of national poverty counties $2.28 \%$ for the period of $1985-1992$ and $0.91 \%$ for the period of 1992-1995 [10]. Mao et al. (2012) show that during the implementation of poverty alleviation program, local government tend to use finance funds for public services especially for production and construction to alleviating poverty [11].

In previous studies, scholars often describe regional social and economic development by GDP. But its accounting is not comprehensive. Unformal economic activities are neglected and some of government officials exaggerate it for promotion [12]. In addition, the connotation doesn't work on measuring impacts on national welfare. Compared with GDP, nighttime light composite data is a better measure of economic de- 
velopment, and has been widely used recently. Yu et al. (2015) have proved that light data can effectively measure the degree of regional poverty [13]. Xu et al. (2015) point out that nighttime light composite data can effectively replace the GDP to measure economic growth [14]. Fan et al. (2016) engage to use lighting data caught by satellites to measure the local economic growth [15].

In summary, the poverty alleviation program has great impacts on the national poverty counties. But it is ambiguous that the impacts of the counties exiting from the program on economic and social development. The paper attempts to use 2011 to 2012 county-level panel data and nighttime light composite data to assess impacts of exiting the program to the previous national poverty counties. As a result, it improves our understanding of poverty alleviation programs and provides scientific guides for drawing up policies for the poverty-stricken area.

\section{Data, Model and Variables}

\subsection{Data and Model Design}

Two types of data are used in this study: (1) NPP-VIIRS nighttime light composite data from 2011 to 2012. (2) Socioeconomic statistics from the China regional statistical yearbook.

NPP-VIIRS nighttime light data are derived from the DMSP program (the U.S. Air Force defense meteorological satellite program). The light data obtained from satellite sensors. The data are collected and published by the National Geographic Data Center (NGDC).

Another main dataset used in this study comes from China regional statistical yearbook, which covers a lot of variables such as, population area, the first industrial output value, the second industrial output value, residents savings, fixed investment and so on.

The main datasets are separated. The article uses the 2007 administrative codes to integrate them into the database. The 2007 administrative codes are the latest version of the national standard administrative codes for counties' identification (national standard GBT 2260-2007). In order to alleviate the pushing of price changes, nominal values in China regional statistical yearbook are divided by provincial CPI from "China Statistical Yearbook".

The validity of our difference-in-differences estimation hinges on the assumption: the treatment group would have followed the same trend as the control group in the case without the adjustment of recipients of the poverty alleviation program. So the samples are defines as counties participated in the third wave national poverty alleviation program from 2001 to 2011. The identification uses the adjustment of lists of national poverty counties initiated in 2011. Those counties which have exited the poverty alleviation program are treated as treatment group. Those counties remained as national poverty counties after the adjustment are regard as controls groups.

The specification for our difference-in-differences estimation is

$$
Y_{i t}=\alpha+\beta D_{i t} \text { Post } 11+\theta X_{i t}+r_{i}+\lambda_{t}+\varepsilon_{i t}
$$


where $i$ and $t$ represent counties and year respectively; $Y_{i t}$ is the measure of economic growth in county $i$ at year $t$ represented by the growth rate of nighttime night; $D_{i t}$ is the designation of previous poverty counties after 2011, taking a value of 1 if it has exited the poverty program and 0 otherwise; Post 11 denotes a post-the third wave poverty alleviation period, taking a value of 1 if it is 2012 and 0 otherwise; $\gamma_{i}$ is the county fixed effect, controlling for all time-invariant differences across counties; $\lambda_{t}$ is the year fixed effect, controlling for all yearly shocks common to counties, such as business cycles; $\alpha$ represents the intercept and $\varepsilon_{i t}$ is the error term. To cope with the potential heteroscedasticity and serial autocorrelation, the paper clusters standard errors at the county level.

Most of labors in poverty-stricken counties are peasants. Their main income comes from the agriculture. Through the grain production, the paper studies the changes of agriculture in the counties which have exited the program since 2011. Besides, fixed investments make big contributions to the economic growth in China. Enterprises in the counties which have exited the program since 2011 may transfer to other areas because they have lost preferential policies as national poverty counties. Finally, the savings of local residents are used to confirm the assumption that the income of peasants in the counties exited from the program fall.

The fiscal situation of poverty counties is closely related to the transfer payments. The transfer payment reductions in counties exited from the program are likely to affect their fiscal operation. In addition, their development of education and health may be impacted by the decrease of fiscal subsidies and economic growth. So the paper uses fiscal revenue and expenditure to analysis the fiscal situation of pre-poverty counties and uses the number of primary school, junior school students and beds in the hospital to study their development of education and health.

\subsection{Variables}

Table 1 describes the economic and social statistics data of poverty counties of the third wave poverty alleviation program, which are defined as examples in the paper. In Table 1 , Light growth and pop growth mean the growth rate of nighttime light and population respectively. The average growth rate of nighttime night is $-4.59 \%$, which suggests that economic development of poverty counties in the third wave poverty alleviation program slow down from 2011 to 2012. Besides, the average population growth rate of the poverty counties is $0.7 \%$, which is close to the national average. The implication of mean of $D_{i t}$ is that there are $3.82 \%$ of counties which have exited from the poverty alleviation program since 2011.

The implications of remain variables are as follows. $1^{\text {st }}$ GDP and $2^{\text {nd }}$ GDP stand for the log of value-added of primary industry and secondary industry. Investment, grain yield and deposit in Table 1 are on the behalf of the log of investment in fixed assets, total grain yield and balance of savings deposit of households. Revenue and expenditure are abbreviations of the log of public budgetary revenue and public budgetary expenditure respectively. Junior schools, primary schools and beds of hospitals denote 
Table 1. Descriptive statistics.

\begin{tabular}{cccccc}
\hline Variable & Count & Mean & Std. Dev. & Min & Max \\
\hline Year & 1112 & 2012 & 0.500 & 2011 & 2012 \\
\hline$D_{\text {it }}$ & 1112 & 0.0342 & 0.182 & 0 & 1 \\
Light growth (\%) & 1112 & -0.0459 & 0.276 & -1.196 & 1.264 \\
Pop growth (\%) & 1099 & 0.0201 & 0.0712 & -0.604 & 0.498 \\
Area & 1112 & 3.967 & 4.006 & 0 & 11.30 \\
$1^{\text {st }}$ GDP $(\log )$ & 1112 & 9.126 & 2.396 & 4.219 & 13.48 \\
$2^{\text {nd }}$ GDP $(\log )$ & 1112 & 9.601 & 2.532 & 3.784 & 15.47 \\
Investment $(\log )$ & 1108 & 10.34 & 2.316 & 4.925 & 15.26 \\
Grain yield $(\log )$ & 893 & 11.69 & 0.953 & 2.565 & 14.16 \\
Deposit $(\log )$ & 1105 & 10.12 & 2.376 & 4.718 & 14.46 \\
Revenue $(\log )$ & 1111 & 7.647 & 2.394 & 1.930 & 13.57 \\
Expenditure $(\log )$ & 1112 & 9.562 & 2.255 & 6.080 & 13.27 \\
Junior schools $(\log )$ & 1112 & 9.656 & 0.873 & 6.933 & 11.69 \\
Primary schools $(\log )$ & 1112 & 10.09 & 0.847 & 7.836 & 14.29 \\
Beds of hospitals $(\log )$ & 1112 & 6.590 & 0.724 & 3.951 & 9.002 \\
\hline
\end{tabular}

logarithms of enrollment of secondary schools and primary schools and number of beds of hospitals and health centers respectively.

\section{Empirical Findings}

Regression results for the difference-in-differences specification (1) are reported in Table 2. This part starts with a simple difference-in-differences specification that includes only counties and year fixed effects in column 1 . The regression coefficient is statistically significant and negative, suggesting that the economic growth of counties which have exited the poverty alleviation program since 2011 fall. Compared with control groups, the economic growth rate of treatment groups reduces $7.4 \%$ after they withdraw from the poverty alleviation program.

In column 2, some control variables are added in the regression such as growth rate of population, area, the first industrial added value and the second industry added value. Evidently, the results are found to be robust.

One could be concerned that our treatment and control groups could be systematically different ex ante, which may spuriously generates the negative effect of economic growth on counties when they exited from the program. However, as displayed in column (3) and (4), compared with counties are treated as national poverty counties in the next poverty alleviation program, counties exited from the program had better performance on economic growth before they were out of the third wave poverty alleviation program. It implies that the regression results of column (1) and (2) are robust.

In Table 3, the three regression shows that the economic and social development 
Table 2. Difference-in-differences results for 2011-2012 changes in growth rate of nighttime light.

\begin{tabular}{ccccc}
\hline & $(1)$ & $(2)$ & $(3)$ & $(4)$ \\
\hline$D_{i t} *$ Post11 & $-0.074^{* *}(-0.034)$ & $-0.083^{* *}(-0.036)$ & & \\
$D_{i t} *$ Post10 & & $0.226^{* * *}(-0.05)$ & $0.260^{* * *}(-0.052)$ \\
Area & $0.033(-0.022)$ & & $-0.001(-0.024)$ \\
Pop (log) & & $0.328^{*}(-0.167)$ & & $0.503^{* * *}(-0.125)$ \\
Pop Growth (\%) & & $-0.096(-0.161)$ & & $-0.127(-0.142)$ \\
$1^{\text {st }}$ GDP(log) & & $0.438^{* * *}(-0.125)$ & & $-0.095(-0.104)$ \\
$2^{\text {nd }}$ GDP(log) & & $1.501^{*}(-0.856)$ & $-0.939^{* * *}(-0.021)$ & $-1.949^{* * *}(-0.651)$ \\
Dummy of year & $0.226^{* * *}(-0.016)$ & $-4.261^{* *}(-2.009)$ & $0.768^{* * *}(-0.01)$ & $3.292^{* *}(-1.639)$ \\
cons & $-0.157^{* * *}(-0.008)$ & 1099 & 1111 & 1085 \\
$\mathrm{~N}$ & 1112 & 0.315 & 0.795 & 0.801 \\
$\mathrm{R}^{2}$ & 0.275 & & & \\
\hline
\end{tabular}

Source: Author's calculation using STATA 13.1. Robust standard errors in parentheses, ${ }^{*} p<0.10,{ }^{* *} p<0.05,{ }^{* * *} p<$ 0.01 .

Table 3. Difference-in-differences results for 2011-2012 changes in investment, grain yield and deposit.

\begin{tabular}{cccc}
\hline & $(1)$ & $(2)$ & $(3)$ \\
\cline { 2 - 4 } & Investment & Grain Yield & Deposit \\
\hline$D_{\text {it }}$ * Post11 & $-0.123^{* *}(-0.057)$ & $-0.018(-0.037)$ & $-0.032^{* *}(-0.013)$ \\
Area & $0.003(-0.019)$ & $-0.020^{*}(-0.012)$ & $0.011(-0.016)$ \\
Pop (log) & $-0.84(-0.84)$ & $-0.506^{* *}(-0.198)$ & $0.371(-0.567)$ \\
Dummy of year & $-4.284^{* * *}(-0.15)$ & $0.241^{\star * *}(-0.09)$ & $-4.490^{* * *}(-0.124)$ \\
cons & $15.379^{* * *}(-2.889)$ & $13.410^{* * *}(-0.689)$ & $11.055^{* * *}(-1.951)$ \\
$N$ & 1108 & 893 & 1105 \\
$R^{2}$ & 0.993 & 0.341 & 0.999 \\
\hline
\end{tabular}

Source: Author's calculation using STATA 13.1. Robust standard errors in parentheses, ${ }^{*} p<0.10,{ }^{* *} p<0.05,{ }^{* * *} p<$ 0.01 .

of previous poverty counties have a significant slowdown after they exited from the poverty alleviation program. It is worth noting that fixed investments in pre-poverty counties fall before long they quit from the program. Grain production has declined in 2011, but not significantly. What's worse, residents' savings significantly decrease, which indicates that per capita income reduces. To sum up, the empirical results of the three columns confirm that the former conclusions in columns 1 and 2 are robust.

Table 4 reports the operation of public finance and the supplies of public goods in counties which have quitted from the program since 2011. After they quit from poverty 
Table 4. Difference-in-differences results for 2011-2012 changes in fiscal position, education and health.

\begin{tabular}{cccccc}
\hline & $(1)$ & $(2)$ & $(3)$ & $(4)$ & $(5)$ \\
\cline { 2 - 6 } & Revenue & Expenditure & Junior Schools & Primary Schools & Beds of Hospitals \\
\hline$D_{i t}$ Post11 & $-0.082^{* * *}(0.028)$ & $-0.086^{* * *}(0.017)$ & $-0.042^{*}(0.024)$ & $0.013(0.021)$ & $-0.025(0.027)$ \\
Pop (log) & $0.230(0.360)$ & $-0.467(0.441)$ & $0.268(0.213)$ & $0.381^{*}(0.206)$ & $0.362(0.442)$ \\
Area & $0.006(0.011)$ & $-0.003(0.006)$ & $0.005(0.008)$ & $0.010(0.008)$ & $0.029^{*}(0.015)$ \\
Dummy & $-4.428^{* * *}(0.083)$ & $-4.382^{* * *}(0.049)$ & $-0.095(0.066)$ & $-0.128^{*}(0.067)$ & $-0.102(0.114)$ \\
of year & & & & & \\
cons & $9.051^{* * *}(1.240)$ & $13.375^{* * *}(1.518)$ & $8.764^{* * *}(0.733)$ & $8.798^{* * *}(0.707)$ & $5.284^{* * *}(1.521)$ \\
$N$ & 1111 & 1112 & 1112 & 1112 & 1112 \\
$R^{2}$ & 0.998 & 0.999 & 0.121 & 0.089 & 0.246 \\
\hline
\end{tabular}

Source: Author's calculation using STATA 13.1. Robust standard errors in parentheses, ${ }^{*} p<0.10,{ }^{* *} p<0.05,{ }^{* * *} p<$ 0.01 .

alleviation program, their public revenues and public expenditures significantly decrease. At the same time, the number of students in their junior school also appeared to decline. This is a serious problem. Education plays an important role in overcoming poverty. The reductions of number of the junior school students may suggest that more youths leave their hometown to work instead of learning knowledge. The fact may aggravate the poverty of rural people in those counties and may lead to vicious spiral. In the end, there is a rise in the number of primary school students, but not significantly. And the number of beds in hospitals and clinics also declined, but not significantly.

It demonstrates that counties exited from the poverty program still need transfer payments from the central government so that problems of education and health will not be deteriorated.

\section{Conclusions}

The existing researches show that the poverty alleviation program has played an important role in increasing the income of the poor and narrowing the gap between the poor and the developed regions. The paper concentrates on the persistent effects of poverty alleviation program. Overcoming poverty is a continuous process. If the development of poverty counties relies on the transfer payments and extrinsic aids, ultimately they are likely to fall into the trap of poverty in the future. As a result, the effect of poverty alleviation program will be greatly reduced. The analysis on economic growth of poverty counties which have exited from the poverty alleviation program since 2011 helps us identify both the persistent effects of poverty alleviation program and development validity of poverty counties after they quit it.

The paper collects from 2011 to 2012 county-level panel data, using difference in difference method to recognize the impacts of quitting the poverty alleviation program for counties on economic growth, fiscal status and education. The conclusions are as fol- 
lows: 1) Economic growth rate of previous poverty counties dropped 7 percentage points. 2) Local fixed investment and savings in the counties exited from the program significantly decrease, which confirms that the economic growth of the counties declines. It means that the counties which have exited from the program still need transfer payment to assure the growth of economic. 3) The fiscal status of poverty counties deteriorates when they have exited from the poverty alleviation program. Besides, the number of students in junior school falls in the previous national poverty counties.

The policy implications of the paper are mainly two aspects. Firstly, the paper confirms that the economic growth of poverty counties falls when they have exited from the poverty alleviation program. Secondly, it finds that the number of junior school students in counties exited from the program decreases. The administration should take it seriously and prevent the vicious cycle of poverty caused by education.

\section{References}

[1] Chinese Rural Investigation Team of National Bureau of Statistics (2000) Poverty Monitoring Report of Rural China in 2000. China Statistics Press, China.

[2] Chinese Rural Investigation Team of National Bureau of Statistics (2012) Poverty Monitoring Report of Rural China in 2011. China Statistics Press, China.

[3] Fang, L.M. and Zhang, X.L. (2007) The Analysis on the Poverty Alleviation Policy in Rural China: Based on Capability Poverty Theory. Journal of Finance and Economics, 33, 47-57.

[4] Meng, L. (2013) Evaluating China’s Poverty Alleviation Program: A Regression Discontinuity Approach. Journal of Public Economics, 101, 1-11. http://dx.doi.org/10.1016/j.jpubeco.2013.02.004

[5] Moretti, E. (2014) Local Economic Development, Agglomeration Economies, and the Big Push: 100 Years of Evidence from the Tennessee Valley Authority. Quarterly Journal of Economics, 129, 275-331. http://dx.doi.org/10.1093/qje/qjt034

[6] The State Council Leading Group Office of Poverty Alleviation and Development (2003) Summary of Poverty Alleviation and Development in Rural Areas of China. China Financial and Economic Publishing Press, China.

[7] Park, A. and Wang, S. (2010) Community-Based Development and Poverty Alleviation: An Evaluation of China's Poor Village Investment Program. Journal of Public Economics, 94, 790-799. http://dx.doi.org/10.1016/j.jpubeco.2010.06.005

[8] Wang, C.Y., Yu, Y.M. and Yuan, L. (2012) An Empirical Study on the Fiscal Poverty Alleviation and Economic Growth in Poverty Counties. Public Finance Research, 6, 23-25.

[9] Zhang, B.B. (2013) Poverty-Alleviation Policy in the New Era: Target Selection and Income Growth of Rural Residents. China Economic Quarterly, 12, 959-982.

[10] Park, A., Wang, S. and Wu, G. (2002) Regional Poverty Targeting in China. Journal of Public Economics, 86, 123-153. http://dx.doi.org/10.1016/S0047-2727(01)00108-6

[11] Mao, J., Wang, D.H. and Bai, C.E. (2012) Poverty Reduction Policies and Local Government Public Spending: An Empirical Study Based on the 8-7 Plan. China Economic Quarterly, 4, 1365-1388.

[12] Tao, R., Su, F.B., Lu, X. and Zhu, Y.M. (2010) Does Economic Growth Lead to Promotion? A Challenge of the Logic of Tournaments and Reevaluation of Provincial-Level Data. Management World, 12, 13-26.

[13] Yu, B., Shi, K., Hu, Y., Huang, C., Chen, Z. and Wu, J. (2015) Poverty Evaluation Using 
NPP-VIIRS Nighttime Light Composite Data at the County Level in China. IEEE Journal of Selected Topics in Applied Earth Observations \& Remote Sensing, 8, 1-13.

http://dx.doi.org/10.1109/JSTARS.2015.2399416

[14] Xu, K.L., Chen, F.L. and Liu, X.Y. (2015) The Truth of China Economic Growth: Evidence from Global Night-Time Light Data. Economic Research Journal, 9, 17-29.

[15] Fan, Z.Y., Peng, F. and Liu, C. (2016) Political Connections and Economic Growth: Evidence from the DMSP/OLS Satellite Data. Economic Research Journal, 1, 114-126.

Submit or recommend next manuscript to SCIRP and we will provide best service for you:

Accepting pre-submission inquiries through Email, Facebook, LinkedIn, Twitter, etc.

A wide selection of journals (inclusive of 9 subjects, more than 200 journals)

Providing 24-hour high-quality service

User-friendly online submission system

Fair and swift peer-review system

Efficient typesetting and proofreading procedure

Display of the result of downloads and visits, as well as the number of cited articles

Maximum dissemination of your research work

Submit your manuscript at: http://papersubmission.scirp.org/

Or contact me@scirp.org 